\title{
Human-Rhesus macaque conflict at Pumdivumdi/ Tallokodi, Pokhara, West Nepal
}

\author{
S. Sharma ${ }^{1^{*}}$ and S. Acharya ${ }^{2}$
}

The study on conflict between human and Rhesus macaque was carried out at Pumdivumdi/Tallokodi in Pokhara valley in March, 2016. Questionnaire survey was carried out in 60 households to assess conflict, economic impact on livelihood of people and identify local deterrent method practiced. Purposive sampling method was used to select respondent for questionnaire survey. Majority of the respondents $(58.3 \%)$ agreed that the damage of crops caused by monkeys was severe. According to $21.7 \%$ respondents, physical hurt and harassment were done by monkeys in the study area. There was a loss of more than NRs. 20,000 in 2015 in $32 \%$ of the total households surveyed. Maize was the most raided crop (31\%) followed by potato $(30 \%)$. Keeping dog in house $(40 \%)$ was the most preferred local deterrent method followed by throwing stone and using catapult (21.7\%).

Key words: Conflict, crop raiding, human, Pokhara, Rhesus macaque

$\mathrm{T}$

There are six species of monkeys in Nepal, Rhesus macaque (Macaca mulatta), Assamese monkey (Macaca assamensis) and Hanuman langurs (Semnopithecus ajax, Semnopithecus entellus, Semnopithecus hector and Semnopithecus schistaceus) (Chalise, 2013). Rhesus monkeys are found in the tropical and subtropical forests in Nepal (Wada, 2005). The Assamese monkey is reported from Mid-hills and High Montana forest of Nepal and its ecological and behavioral details are still largely unknown (Chalise, 2006). Rhesus macaques are indigenous species of Bangladesh, India, Pakistan, Burma, Nepal, Thailand, Vietnam, Afghanistan, Southern China and some neighboring places.

Rhesus monkeys belong to the Cercopithecidae family (primate's order). According to IUCN, the Rhesus macaque is one of the least concerned primates in the world (Timmins et.al 2008). It is commonly found in the Terai and Mid-hills of Nepal (Aryal and Chalise, 2013). Rhesus monkeys are both arboreal and terrestrial. They eat fruits, leaves, roots, seeds, flowers, buds, soil, insects and other small animals (Rowe, 1996). Primates are problematical because control measures are usually not successful (Strum, 1994). Crop raiding is one of the causes of conflict from nonhuman primates which is mainly associated with farmers (Air, 2015).

The competition between human and non-human primates is a major problem in some areas where they are sharing the same food resources. Globally, primates are being problematical because of stealing food from human settlement or garbage found around forest and urban areas to supplement their natural diet. Further, monkeys are being more aggressive towards human (Sharma et al., 2011). Due to this reason, monkeys are not liked in the areas of massive agriculture, horticulture and other plantations since they eat and damage the crops and orchards (Roonwal and Mohnot, 1977). Monkeys have become commensalism and competitors of human being in and around villages, towns and cities. These are "Urbanized monkeys" (Rajpurohit et al., 2006).

The main reason behind human-monkey conflict is the massive cutting of fruit trees and plantation

1 Kimdanda-1, Arghakhanchi, *E-mail: me.sonia07@gmail.com

2 District Climate Change Specialist at ASHA Project 
of exotic commercial species which do not supply food to monkey; this compels the monkeys to enter into human residential areas and crop fields. (Ahsan, 2014). When it is short supply of natural food, high quality and easily digested human food becomes alternative nutrition for monkey, which is the most important cause of crop raiding (Horrocks and Baulu, 1994). Hence, this negative attitude due to crop raiding has brought a question mark in the conservation of monkeys. In developing countries, farmers have limited economic source and rarely get compensation for their losses which leads severe negative attitude towards monkey (Nyhus et al., 2005, Linkie et al., 2007). Furthermore, farmers' incapability to cope with crop-raiding, lack of compensation schemes and economic loss leads to retaliatory killing of this species (Nyhus et al., 2005).

Crop raiding is a genuine reason for conflict between human and primates. In Nepal, crop damage is very common in the Mid-hills, High Mountain, Terai and immediate periphery of national parks and reserves. Primates are considered as the pest of field crops, Langurs in Sworgadwari forest of Pyuthan, Sangekhola of Tanahun, Assamese macaques of Hariharpur Gadhi, Rhesus macaques in Ghodaghodi of Kailali and Pashupati, Swoyambhu, Thapathali and Sankhu of Kathmandu, and elsewhere (Chalise, 2000).

\section{Materials and methods}

\section{Study area}

This study was carried out at Pumdivumdi/ Tallokodi, ward no. 25 of Pokhara Metropolitan city in Kaski District of Nepal. The study area 'Pumdivumdi' was selected as there was a serious issue of conflict between human and Rhesus monkey since last three years.

The study area is located at $78^{\circ} 66^{\prime} 75.5^{\prime \prime} \mathrm{E}$ longitudes and $31^{\circ} 22^{\prime} 80.6^{\prime \prime} \mathrm{N}$ latitudes and at an elevation of $1234 \mathrm{~m}$. This area is dominated by Aryans and their main occupation is agriculture. This area is a tourist center too as it is near to Phewa lake and World Peace Pagoda. The population of Pumdivumdi was 7,391 (BS,2011)

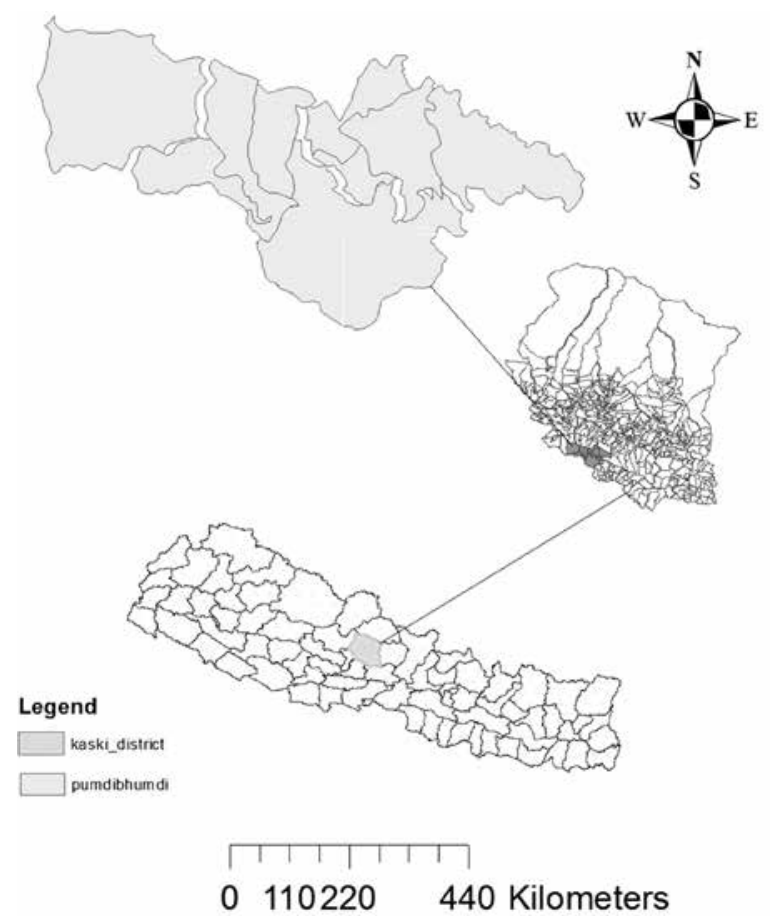

Fig. 1: Map showing the study area 'Phumdivumdi/Tallokodi'

\section{Questionnaire survey}

Purposive sampling method was used for questionnaire survey and 60 households were selected for this study. A pre-tested close and open ended questionnaire was used to collect the information from respondents. The information collected were period of monkey visit, monkey related problems, deterrent methods used by the locals, possible remedial measures of conflict.

\section{Focus group discussion}

Focus group discussion was conducted in the study area by representing all categories of users. The main issues regarding conflict, response of concerned authorities and resolving methods were discussed in the focus group discussion.

\section{Informal discussion}

Informal discussions were carried out with different key informants: executive committee members, teachers, elder persons, local leaders and social workers to get the overall information on human-Rhesus macaque conflict and verify the information collected in the focus group discussion. 


\section{Secondary information}

Secondary sources of information such as published papers, theses, and reports were reviewed.

\section{Data analysis}

Data obtained were fed into Ms-Excel and Statistical Package for Social Sciences (SPSS) and analyzed accordingly. Results were presented in the tabular and graphic form.

\section{Results and discussion}

\section{Frequency of monkey visit}

Forty-five per cent of the total respondents accepted that monkeys were seen twice a day (Table 1).

Table 1: Frequency of monkey visit

\begin{tabular}{|l|c|c|c|}
\hline Description & Frequency & $\begin{array}{c}\text { Per } \\
\text { cent }\end{array}$ & $\begin{array}{c}\text { Cumulative } \\
\text { Per cent }\end{array}$ \\
\hline $\begin{array}{l}\text { Every day } \\
\text { Once in a } \\
\text { day Twice in } \\
\text { a day More } \\
\text { Total }\end{array}$ & 9 & 15.0 & 15.0 \\
\cline { 2 - 4 } & 14 & 23.3 & 38.3 \\
\cline { 2 - 4 } & 10 & 45.0 & 83.3 \\
\cline { 2 - 4 } & $\mathbf{6 0}$ & $\mathbf{1 0 0 . 0}$ & 100.0 \\
\hline
\end{tabular}

\section{Problems caused by monkey}

Ninety-two per cent respondents of Hetauda (McCourt, 2005), 78\% respondents of Lamjung (Adhikari,2013) and 76\% respondents of Vijayapur area of Dharan reported crop raiding was main problem. Likewise, in this study, 58.3\% respondents said that crop raiding was a serious problem for them (Fig. 2). Similarly, majority of the respondents (43\%) strongly agreed that people were suffered from monkeys $10-15$ times in a month (Fig. 3).

Thirty-two per cent respondents stated that there was annual financial loss of more than NRs. 20,000 due to crop damage followed by financial loss of $10000-20000$ (30\% respondents) (Fig.4).
Problems caused by monkey

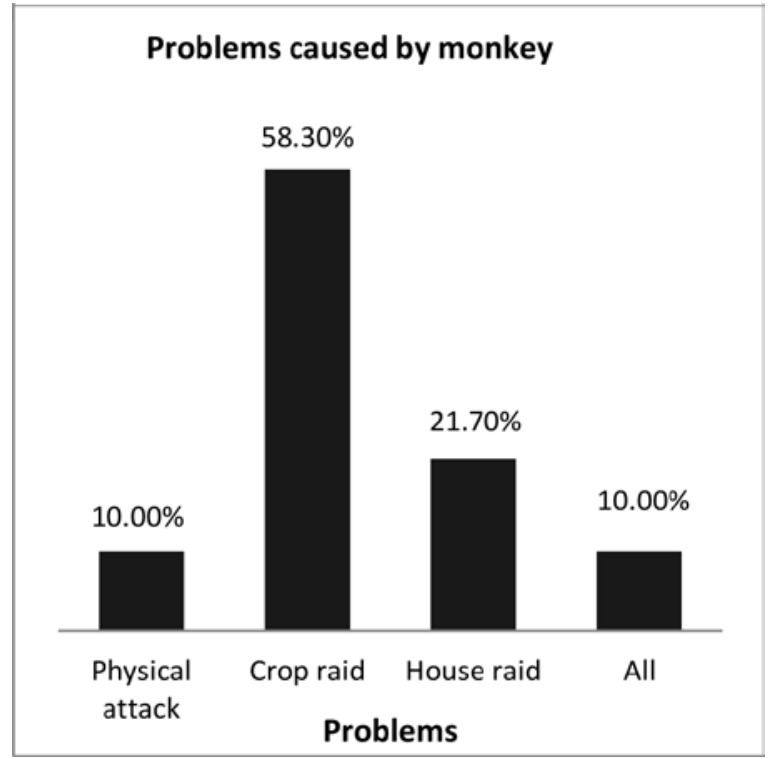

Fig. 2: Problems of the respondents

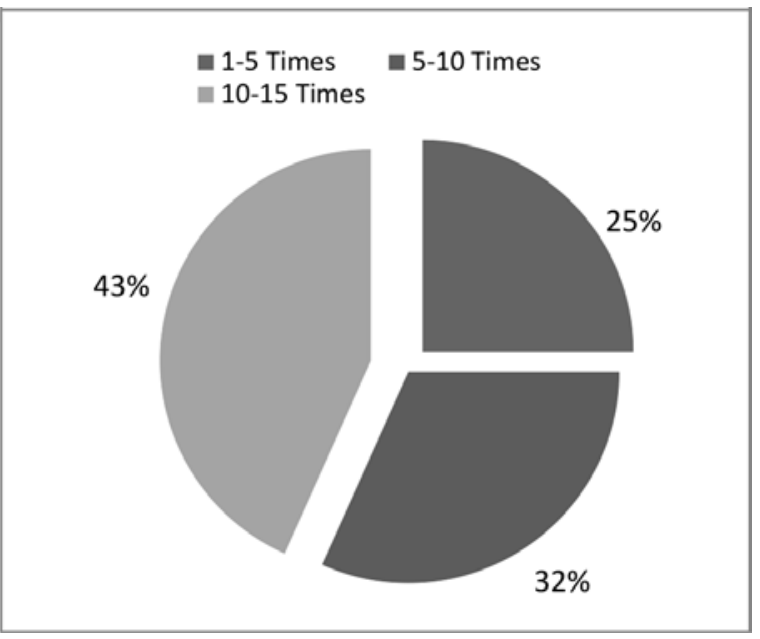

Fig. 3: Frequency of problems in a month

Annual financial loss due to damage of crops by monkeys

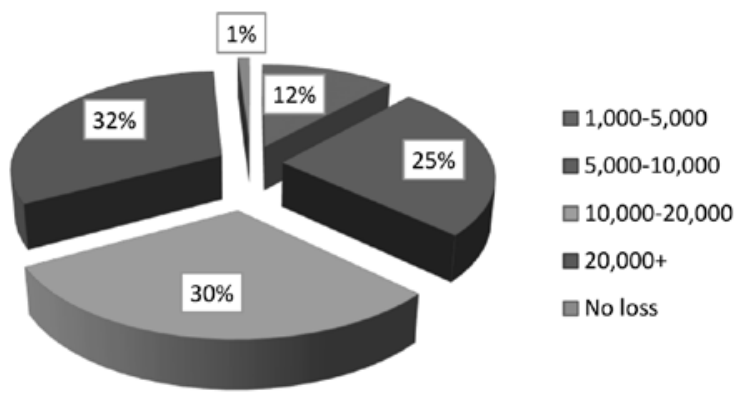

Fig. 4: Annual financial loss of individual family by monkeys 


\section{Most raided crops by monkey}

According to the respondents, mostly monsoon crops i.e. maize, wheat, millet, rice and vegetables such as potato, cauliflower, cabbage and guard were raided most. Thirty-one per cent respondents agreed that the most raided crop was maize (Fig. $5)$.
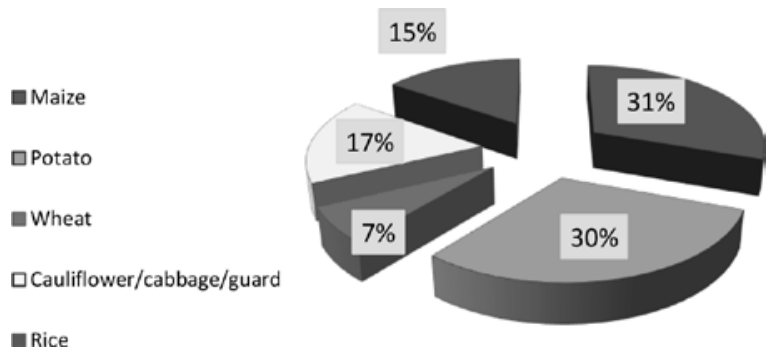

Fig 5: Most raided crops by monkeys

\section{Local deterrent methods for monkeys}

Forty per cent respondents opined that using dog was the effective deterrent method for monkeys which was followed by throwing stone and using catapult (21.7\%) (Fig. 6). In the study of McCourt (2005) in Hetauda, 40\% respondents agreed the deterrent method was throwing stone and using catapult.

Other strategies included flame rally to chase monkey, playing music through cassette player or radio with loud sound as well as planting thorny plants and non-palatable crops by farmers to prevent crop raiding.

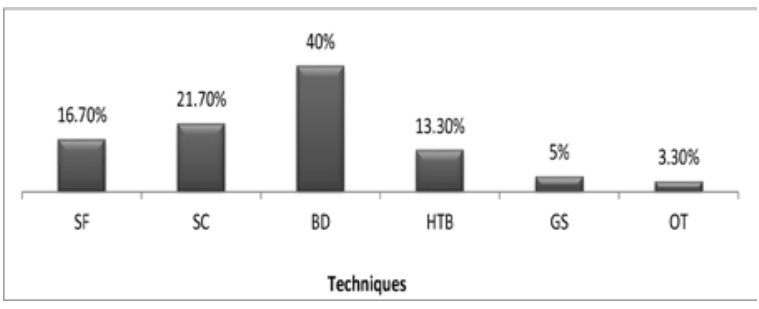

Fig.6: Local deterrent methods for monkeys (SF- shout and follow, SC- throwing stone and use of catapult, BD- by dog, HTB- hitting tin boxes, GS- gun shooting, OT-others)

\section{Perception of people towards the conservation of Rhesus macaque}

The response of majority of people towards the question asked on conservation of the species for ecosystem balance was negative i.e. $61.7 \%$ people denied for conservation (Table 2).

Table 2: Perception of people towards conservation of species

\begin{tabular}{|c|c|c|c|}
\hline Description & Frequency & Per cent & $\begin{array}{c}\text { Cumulative } \\
\text { Per cent }\end{array}$ \\
\hline \multirow{2}{*}{ Yes } & 10 & 16.7 & 16.7 \\
\cline { 2 - 4 } $\begin{array}{c}\text { No } \\
\text { Don't Know } \\
\text { Total }\end{array}$ & 37 & 61.7 & 78.3 \\
\cline { 2 - 4 } & 13 & 21.7 & 100.0 \\
\hline
\end{tabular}

\section{Interventional support}

None of the respondents have got interventional support from government or private agencies till this date. Also Rhesus macaque is not included in the list of animals in Wildlife Damage Relief Guideline (MFSC,2069)

\section{Conclusion}

From this study, it is found that severe humanRhesus conflict exists in the study area due to crop raiding for four years which has compelled people to change crop pattern i.e. they have stopped growing potato and maize. In spite of Pokhara being a tourist center, people of Pumdivumdi are suffering a lot from Rhesus macaque which has led people to shift towards home stay business from agriculture. Majority of the respondents bear loss of NRs. 20,000+ due to crop raiding. Mostly, monsoon crops (maize, wheat, millet) and vegetables (potato, cauliflower, guard, and cabbage) are raided by Rhesus macaque during the month of March to July. This clearly implies that crop raiding was the serious issue in the study area that has severe impact on livelihood and economy of farmers. Besides financial loss, five dogs were killed by Rhesus attack and locals were also injured.

None of the related authorities is concerned about this issue in the study area. Neither interventional support is provided nor included in any legal document. The loss due to Rhesus macaque and negligence of concerned authorities has heightened negative attitude of people towards the species. This negative attitude has put question mark in the conservation of this species. 


\section{References}

Adhikari, R. K. 2013. Population Status, Distribution and General Behavior of Assamese Macaque (Macaca assamensis, McClelland) in Taghring and Ghermu VDCs, Lamjung, Nepal. M. Sc. Thesis. Central Department of Zoology, Tribhuvan University, Nepal.

Ahsan, F. M. and Uddin Mazbah, M. 2014. Human-Rhesus monkey conflict at Rampur village under Monohardi Upazila in Narsingdi District of Bangladesh, Journal of Threatened Taxa 6 (6) : 5905-5908. www.threatenedtaxa.org.

Air, A. 2015. Crop Raiding and Conflict: Study of Rhesus macaque-Human Conflict in Shivapuri-Nagarjun National Park, Kathmandu Nepal, Natural Resources Management, Norwegian University of Science and Technology, Norway.

Aryal, K. and Chalise M. K. 2013. Human-monkey interface in Arkhale and Nayagaun, Gulmi, West Nepal. Nepalese Journal of Zoology 1 (1) : $30-40$.

CBS,2011. National Population and Housing Census 2011., Government of Nepal, National Planning Commission Secretariat Nepal, Central Bureau of Statistics (CBS), Kathmandu, Nepal.

Chalise, M. K. 2006. Primate census in different parts of Nepal. Journal of the University Campus TUTA, TU, Prospective on Higher Education, 2, 35-41.

Chalise, M. K. 2000. Crop raiding by wildlife, specially primates and indigenous knowledge of food conservation. Asian Primates 7(3-4):4-9.

Chalise, M. K. 2013. Fragmented primate population of Nepal. In Primates in Fragments (eds.) Marsh, L. K. and Chapman, C. A., Springer, London, 329356.

Horrocks, J. A., and Baulu, J. 1994. Food competition between vervets (Cercopithecus aethiops sabaeus) and farmers in Barbados: implications for management. Revue D Ecologie-La Terre Et La Vie 49: 281-294.

Linkie, M. , Dinata, Y. , Nofrianto, A. and LeaderWilliams N. 2007. Patterns and perceptions of wildlife crop raiding in and around
Kerinci Seblat National Park, Sumatra. Animal Conservation 10 : 127-135.

McCourt, P. 2005. Urban Human-Monkey Conflict in the Vicinity of the Institute of Forestry, Hetauda, Nepal.

MoFSC, 2069. Wildlife Damage Relief Guideline. Government of Nepal, Ministry of Forest and Soil Conservation (MoFSC),Kathmandu, Nepal.

Nyhus, P. J.,Osofsky, S. A. , Ferraro, P. , Madden, F. and Fisher, H. 2005. Bearing the cost of human-wildlife conflict: the challenge of compensation schemes. In People and wildlife conflict or coexistence? (eds.) Woodroffe, R., Thirgood, S. and Rabinowitz, A., Cambridge University Press, Cambridge, 107-121.

Rajpurohit, L. S., Chhangani, A. K. , Rajpurohit, R. S., Bhaker, N. R., Rajpurohit, D. S. and Sharma, G. 2006. Man-monkey conflict and urbanization in nonhuman primates. Int. J. Primatol 27 (1) : 117.

Roonwal, M.L. and Mohnot, S. M. 1977. Primates of South Asia : Ecology, Sociobiology and Behavior. Harvard University Press, Cambridge.

Rowe, N. 1996.The Pictorial Guide to the Living Primates. Charlestown, Rhode Island: Pogonias Press.

Sharma, G., Ram, C. and Rajpurohit, L.S. 2011. Study of man-monkey conflict and its management in Jodhpur, Rajasthan (India). Journal of Evolutionary Biology Research 3 (1) : $1-3$.

Strum, S. C. 2010. The development of primate raiding: implications for management and conservation. International Journal of Primatology $31: 133-156$.

Timmins, R.J., Richardson, M., Chhangani, A. \& Yongcheng, L. 2008. Macaca mulatta. The IUCN Red List of Threatened Species 2008:e.T12554A3356486. http://dx.doi. org/10.2305/IUCN.UK.2008.RLTS. T12554A3356486.en.

Wada, K. 2005. The distribution pattern of rhesus and Assamese monkeys in Nepal. Primates, 46 (2) : 115-119. 